\title{
A perspective on the potential of using marine organic fertilizers for the sustainable management of coastal ecosystem services
}

\author{
Iraj Emadodin ${ }^{1} \cdot$ Thorsten Reinsch $^{1} \cdot$ Ana Rotter $^{2} \cdot$ Martina Orlando-Bonaca $^{2} \cdot$ Friedhelm Taube $^{1}$. \\ Jamileh Javidpour ${ }^{3,4}$
}

Received: 6 June 2019 / Revised: 5 December 2019 / Accepted: 27 January 2020 / Published online: 7 February 2020

(c) The Author(s) 2020

\begin{abstract}
Agricultural production is predicted to double during the next century. To ensure food security in response to global population growth is a challenge and will require strategies that mitigate associated environmental damage in ways consistent with United Nation's Sustainable Development Goals. One possible approach is to utilize organic fertilizers from marine sources to improve soil structure by enhancing activities of soil organisms and restoring essential plant nutrients to the soil. Here we identify opportunities to develop organic fertilizers from two types of materials of marine origin: seagrass wrack and jellyfish biomass. Seagrass wrack often occurs as undesirable waste material on beaches. In many coastal areas around the world jellyfish bloom presents a nuisance because of negative impacts on marine ecosystem productivity. Several investigations have reported that organic fertilizers produced from seagrass and jellyfish could enhance coastal ecosystem services by reducing pollution, and by improving soil health and quality. Recent research indicates that seagrass litter improves soil water holding capacity and the nutritional value of crops; moreover, it can be used as multi-functional fertilizer, due to its content of valuable macro- and microelements. The application of jellyfish fertilizer increases soil contents of organic matter, nitrogen, phosphorus and potassium and enhances the growth and survival of seedlings significantly. In this overview we describe novel approaches regarding the utilization of seagrass and jellyfish as sources of fertilizer, and experimental studies on the influences of marine organic fertilizers on soil restoration, and implications for coastal management.
\end{abstract}

Keywords Seagrass $\cdot$ Jellyfish $\cdot$ Soil ecosystem $\cdot$ Sustainable agriculture $\cdot$ Soil fertility $\cdot$ Blue economy

\section{Introduction}

The world's population is projected to reach around 9.5 billion by 2050 and it is predicted that agricultural production will need to be nearly doubled to ensure global food security (Lal 2006; FAO 2009; Pradhan et al. 2015; Prosekov and Ivanova 2018). Soil is a fundamental resource

Iraj Emadodin

iemadodin@gfo.uni-kiel.de

1 Institute for Crop Science and Plant Breeding-Grass and Forage Science/Organic Agriculture, University of Kiel, Kiel, Germany

2 Marine Biology Station, National Institute of Biology, Piran, Slovenia

3 Department of Biology, University of Southern Denmark, Odense, Denmark

4 GEOMAR, Helmholtz Centre for Ocean Research, Kiel, Germany for agricultural development and it has direct and indirect effects on almost all aspects of human life. The overuse of soil as a consequence of inappropriate management to meet increasing food demand, including intensive use of fertilizers and pesticides and monoculture cropping, has had direct and adverse effects on soil ecosystem functions and services. Therefore, population growth and soil degradation are often closely linked (Emadodin and Bork 2012; Emadodin et al. 2019). Moreover, the conversion of woodland and rangeland into agricultural land for crop and biofuel production has accelerated and triggered additional environmental loads (Millennium Ecosystem Assessment 2005; Emadodin et al. 2009; Lobell et al. 2011; Bedunah and Angerer 2012; Taube et al. 2014; Lal 2015; Vimal et al. 2017). Despite soil degradation, however, crop production has increased in many regions (Hatfield 2012; Thierfelder et al. 2015) through the use of improved genetics, more effective pest control and better management practices (Badgley et al. 2007; Adolwa et al. 2017). 
Based on current management practices and levels of production intensity, the world demand for the main fertilizer nutrients (nitrogen $[\mathrm{N}]$, phosphorus $[\mathrm{P}]$ and potassium $[\mathrm{K}]$ ) is predicted to rise by $2 \%$ annually (FAO 2017). In 2015 the total annual fertilizer (nutrient) demand was estimated at around 184 million tonnes and was projected to reach 202 million tonnes by the end of 2020 (Fig. 1). However, when the fertilizer value of organic manures from animal husbandry are included with that from mineral fertilizer applications, situations may arise, especially in intensive agricultural production systems, where there are positive nutrient surpluses, resulting in reduced soil and water quality, and associated toxicity problems for humans and plants (Guo et al. 2010). Moreover, there is a high energy-cost associated with production and application of mineral fertilizers, and an associated environmental impact in terms of greenhouse gas (GHG) emissions (Christiansen et al. 2012). The overuse of $\mathrm{N}$-fertilizers has been a widespread problem

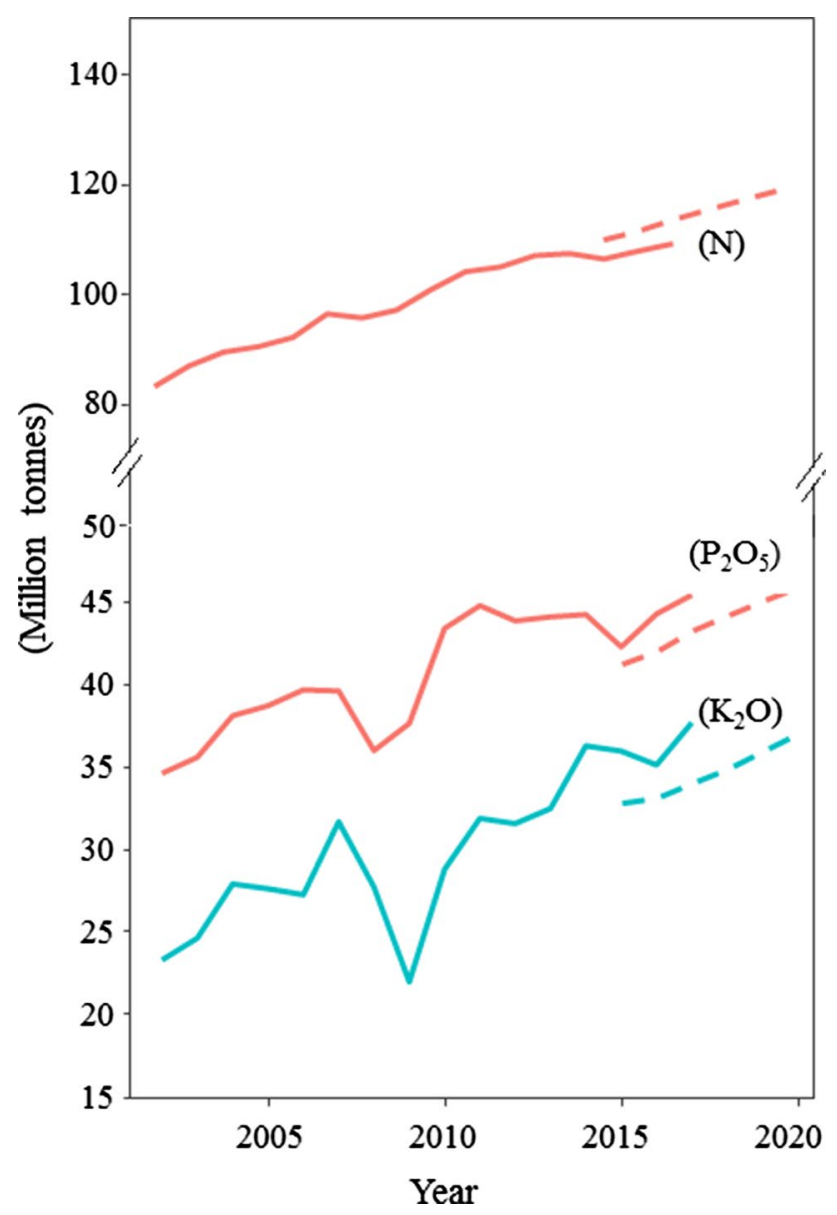

Fig. 1 Global mineral fertilizer consumption (solid line) and prediction (dash line). The prediction was made by FAO in 2017 using actual data until 2015 but the data obtained from 2016 and 2017 show consumption of fertilizer more than the prediction for $\mathrm{P}_{2} \mathrm{O}_{5}$ and $\mathrm{K}_{2} \mathrm{O}$. Source: FAO $(2017,2019)$ in many countries, and it remains an ongoing problem in developing countries particularly where there are expanding urban areas and high rates of population growth (Mikkelsen and Bruulsema 2005; Miao et al. 2011; Arora et al. 2018). As an example, Zhang et al. (2007) reported that in China in the years 2000 and 2002 the average $\mathrm{N}$ application rates were 215,187 and $209 \mathrm{~kg} \mathrm{ha}^{-1}$ for rice, wheat and maize, respectively, with continuously increasing rates in many regions during the recent years leading to positive $\mathrm{N}$ balances of $93-120 \mathrm{~kg} \mathrm{~N} \mathrm{ha}^{-1}$ year $^{-1}$ (He et al. 2018). Surplus $\mathrm{N}$ balances increase the potential for high GHG-emissions, particularly as $\mathrm{N}_{2} \mathrm{O}$ released from fertilized soils (Dobbie et al. 1999; Reinsch et al. 2018); as well as contributing to groundwater pollution by nitrate (Rahmati et al. 2015). Hence, there is a need for locally adapted sustainable agricultural practices and investments in different agricultural sectors to enable development of strategies for 'environmentally smart' agricultural practices (Rashid et al. 2016; Vimal et al. 2017) and thereby help ensure future food production and agricultural sustainability.

One of the key elements in agriculture is to close nutrient cycles as far as possible. The main components of many agricultural systems are organic fertilizers. These contribute to soil fertility by improving microbial activities, as well as by mobilizing fixed macro- and micro-nutrients or by converting insoluble $\mathrm{P}$ in the soil to plant-available forms (Mishra et al. 2013). In this context, animal manures are often used, as they provide a readily available by-product from the animal production chain. However, despite their ability to convert cellulose-rich plant material into valuable meat and dairy food products, ruminant production systems in particular are often linked to other environmental tradeoffs. These include emissions of the GHGs such as methane and nitrous oxide. Therefore, an important research challenge is to identify and bring to market alternative and new organic fertilizers that combine the nutrient-use efficiency of inorganic fertilizers with the beneficial effects of common organic manures, including enhanced soil carbon storage (Loges et al. 2018), microbial activity (Murugan et al. 2013), and water holding capacity, particularly important for improving the productivity of extensive or strongly degraded soils.

The use of green manures, whereby green standing biomass is incorporated into the soil, is a technique that has potential for improvement of fertility especially of soils that have low organic matter. Forage legumes, such as white clover and red clover (Trifolium repens L.; Trifolium pratense L.) are often used for this purpose because of their high productivity, associated with $\mathrm{N}$-fixation, and high efficiency of nutrient cycling (Schmeer et al. 2014) within a crop rotation (Loges et al. 2018; Brankatschk and Finkbeiner 2017). In ruminant livestock farming systems, forage legumes are widely used to provide both grazed and conserved feed of 
high nutritive value, at relatively low cost, and they are effective in utilizing soil nutrients including those derived from animal excreta. However, the global use of forage legume crops is limited because of difficulties, compared with grass crops, in maintaining their persistence under grazing as well as difficulties associated with conservation for silage or hay (Phelan et al. 2015). In addition, the global increase in livestock numbers, often at increased stocking densities, has contributed to many of the environmental burdens associated with land-based food production (Steinfeld et al. 2006).

The world's oceans, on the other hand, which cover more than two-thirds of the earth's surface, have potential to supply many resources, largely unexplored at present. Furthermore, in coastal areas, the sea has long been a source of organic fertilizers. For instance, seaweed or benthic marine algae have largely been used for their fertilizer value and a source of many essential nutrients, which have a role in promoting seed germination and enhancing yield and crop health (Sathya et al. 2010). Moreover, seagrasses and jellyfish (Medusozoa) are also two additional sources of marine organisms that have potential for use as organic fertilizers, and the possibilities for their use will be considered in this overview.

Therefore, the aims of the current review article are to investigate the possible use of seagrasses and jellyfish as alternative sources of organic fertilizers, and provide suggestions for future investigations in this field.

\section{The roles of seagrass and jellyfish in the context of ecosystem services}

\section{Seagrass}

Seagrasses are considered to be an ecologically important mixed group of marine plants, which grow in shallow marine coastal waters worldwide and are considered as indicators of healthy marine and coastal ecosystems (Short 1987; Kenworthy and Fonseca 1992). They provide shelter, food, and essential nursery areas for diverse invertebrates and fish communities (Hemminga and Duarte 2000; Boström et al. 2004; Spalding et al. 2003). In terms of taxonomy they are marine angiosperms and comprise of two families, twelve genera and around seventy two species (Short et al. 2007), with the richest species diversity in the Indo-Pacific area and the Red Sea, while only four native seagrass species are found in European coastal zones (Borum and Greve 2004; Boström et al., 2014; Wahab et al. 2017). According to a review by Milchakova et al. (2014), there are large meadows of seagrass in every continent except Antarctica, and the tropical zone has the greatest distribution and diversity of marine angiosperms. Among them, the Little Neptune grass $(C$. nodosa $)$ is the most common species in shallow sheltered to semi-exposed sites in the Mediterranean basin (Den Hartog 1970), where also the non-indigenous and invasive Halophila stipulacea (Forsskål) Ascherson, is present in warmer waters (Verlaque et al. 2015). The Common eelgrass (Zostera marina L.) is the dominant seagrass species in the northern temperate zone and it has a wide clonal growth in the non-tidal Baltic Sea (Worm and Reusch 2000; Hämmerli 2002).

Seagrasses provide many important ecosystem services, food webs dynamics and ecological resilience, and therefore any intensive utilization of these plants could cause significant impacts on coastal ecosystems and their services (Hubbard and Dugan 2003; De la Torre-Castro and Rönnbäck 2004; Davenport and Davenport 2006; Mossbauer et al. 2012). In addition, seagrass beds are known to trap fine sediments and other particles suspended in the water column; this increases water transparency and provides protection against coastal erosion (Terrados and Borum 2004). These marine plants are also able to extract macronutrients from water and sediments, and they also show high tolerance to pollution and high capacity for accumulation of trace elements (Bonanno and Orlando-Bonaca 2017). Because of their key ecosystem services, seagrass beds rank among the most valuable ecosystems in the biosphere (Costanza et al. 1997) and are recognized as one of the priority habitats in the EU Habitat Directive (HD, 92/43/EEC). Eventually, a correct assessment of the status of seagrass meadows is crucial for the implementation of the EU Water Framework Directive (WFD), and the Marine Strategy Framework Directive (MSFD) (Orlando-Bonaca et al. 2015).

Although there has been only limited direct use of seagrass as a green mass, there is evidence of its long-term use as dead material by humans (Hämmerli 2002; Spalding et al. 2003). According to Milchakova (2008), dry leaves of $Z$. marina were found in the Egyptian pyramids, as well as in many burial mounds of the Bosporus Kingdom in the 6th century BC and in the Middle East around two thousand years ago (Lipkin et al. 2003). Since ancient times, European coastal people have used seagrass dead material as soil organic amendments, fodder (in the North West European countries), and for mattress filling, mulch, fuel, insulation, roofing materials and underlay for livestock (Heywood 1996). According to Hemminga and Duarte (2000) the seeds of marine eelgrass were a food resource of the Seri Indians living along the Gulf of California and the seeds of Enhalus acoroides (L. f.) Royle are still used as a food in coastal area of South-East Asia. Powder, obtained from the seeds, was also used to make dishes (Hemminga and Duarte 2000). The high silica content and the air pockets formed in dead seagrass make it an ideal insulation material (Wyllie-Echeverria and Cox 1999; Harrison 1989). The dead material (litter) has also been used historically for the formation of dykes to help prevent beach erosion (Wyllie-Echeverria and Cox 
1999). These activities are somewhat localized to specific regions since some of the historical benefits of seagrass are now satisfied with more practical, efficient and cheaper alternatives. Furthermore, seagrass litter has also been used as traditional medicine and fertilizers (de la Torre-Castro and Rönnbäck 2004). Different species of seagrasses have different applications. As an example, buoyant species can float over long distances and may be washed up on beaches in large amounts. In these situations, the dead material could have a number of applications including erosion prevention, and mulch for gardening. Moreover, some companies have used seagrass material to produce specific nutrient mix for horticultural use, but there have been only a few such cases reported in the literature (El Din and El-Sherif 2013; Grassi et al. 2015).

Moreover, the results of the P.R.I.M.E. project (Posidonia, Residues Integrated Management for Eco-sustainability) showed that the reuse of residues of Neptune grass (Posidonia oceanica) as a compost for local agricultural purposes, leads to a $65 \%$ decrease in the costs of disposal of beached biomass (P.R.I.M.E. 2014).

Current conservation policies in most parts of the world prevent harvesting of live and fresh seagrass material (Filipkowska et al. 2009). This prohibition may cause indirect economic damage in some coastal areas, and therefore, harvesting methods based on sustainable utilization should be developed. For example, during the summer season, accumulation of seagrass in the Polish and German coastal areas creates some problems for tourism in terms of visual appearance of beaches and coastal waters (Filipkowska et al. 2009; Mossbauer et al. 2012;). The accumulation of seagrass litter (about $2 \mathrm{~m}$ thick) on sandy Australian beaches was reported by Short (1987). Mossbauer et al. (2012) recorded the accumulation of around 4900 tonnes of eelgrass (Z. marina) litter on the German Baltic coast, between May and October 2010. In order to improve the socio-economic benefit of the coastal area, five pilot research projects, with a socioeconomic perspective and approach, were carried out along the German Baltic coastline between 2001 and 2007. Their aim was to achieve a scientific and technological basis for the reorganization of beach wrack management to create new jobs, to improve benefits to the local economy, to bring down the costs of beach cleaning, and to enhance the capacity utilization rate of recycled beach wrack (Mossbauer et al. 2012). As an example, one of the targets of these pilot projects was to use marine eelgrass for a progressive coast wrack management by producing insulation mats, regenerative energy, animal litter and cosmetics (Mossbauer et al. 2012). The authors emphasized that a new strategic management has to concentrate on cost depletion and conservation of beach ecosystems in the future. Furthermore, direct or indirect socioeconomic impacts of seagrass litter accumulation on coastal attractiveness and local income have not been analysed in detail and more investigations are needed. Therefore, from our point of view, the sustainable utilization of seagrass dead organic matter as an organic fertilizer may play an important role in agroecosystems in coastal areas in the near future.

\section{Jellyfish}

Global warming has caused serious impacts on marine and terrestrial biomes, for example by increasing both the frequency and magnitude of jellyfish blooms especially in some temperate regions (Eriksen et al. 2012; Gibbons and Richardson 2013; Lucas et al. 2014). In many coastal areas around the world, jellyfish bloom is considered a nuisance. This arises because of their negative impacts on ecosystem productivity through decreasing harvested valuable fish stocks (Pauly et al. 2009; Graham et al. 2014), limiting carbon and energy flow to higher trophic levels (Condon et al. 2011), clogging cooling water systems of power plants (Fukushi et al. 2003) and by causing negative economic influences on coastal infrastructure, aquaculture and tourism (Purcell 2005; Purcell et al. 2007). In addition, they can present a considerable hazard to public health by producing harmful toxins (De Donno et al. 2014). However, jellyfish can be harvested and converted to new materials and this would help to reduce their numbers in the sea. Hence, some efforts have been made to use jellyfish as an alternative resource. In East Asia jellyfish are traditionally valued, as a seafood, often served as a cold dish or in salad. Moreover, ancient and modern Chinese medical books indicate their use in traditional Chinese medicine (Omori and Nakano 2001; You et al. 2007). Therefore, due to the special nutritional and medicinal values attributed to jellyfish, some related businesses such as gastronomy and fishery contribute millions of dollars each year to Asian economies (You et al. 2007). Some species of jellyfish are rich in collagenous protein and therefore, have recently been considered as an important collagen resource for use in the cosmetic industry (Zhuang et al. 2009; Boero 2013). They also have potential insecticidal properties: Yu et al. (2005) determined the insecticidal activity of proteinous venom from tentacles of Rhopilema esculentum against different plant pest species, and Yu et al. (2014) showed positive effects of Stomolophus meleagris against the cotton bollworm (Helicoverpa armigera).

\section{The importance of using marine organic fertilizers}

\section{The impacts of marine organic fertilizer on the environment}

A schematic representation of the environmental impacts of chemical fertilizers versus organic fertilizers (obtained from jellyfish and seagrass), is shown in Fig. 2. Strong collaboration between research centres and industry partners 
is needed to improve the quality of marine fertilizers. A sustainable production and utilization of marine products could also contribute to the blue growth or blue economy in marine sectors, as published by the European Commission in 2012 (EC 2012; Lillebø et al. 2017). Additionally, the monitoring of each step of the fertilizer production and environmental assessments are recommended. Finally, it is hypothesised that in the future, organic fertilizers of marine origin could partly substitute for other organic and mineral fertilizers in order to reduce environmental pollution and to close nutrient deficits in coastal regions. Moreover, positive feedbacks on soils might improve the hydrological cycle by increasing water holding capacity and nutrient-use efficiency. Therefore, the input of harmful elements into soil and ground water would be reduced. The actions proposed in Fig. 2 follow the UN Sustainable Development Goals (SDGs) "a call for action by all countries to promote prosperity while protecting the planet", adopted in 2015 by the

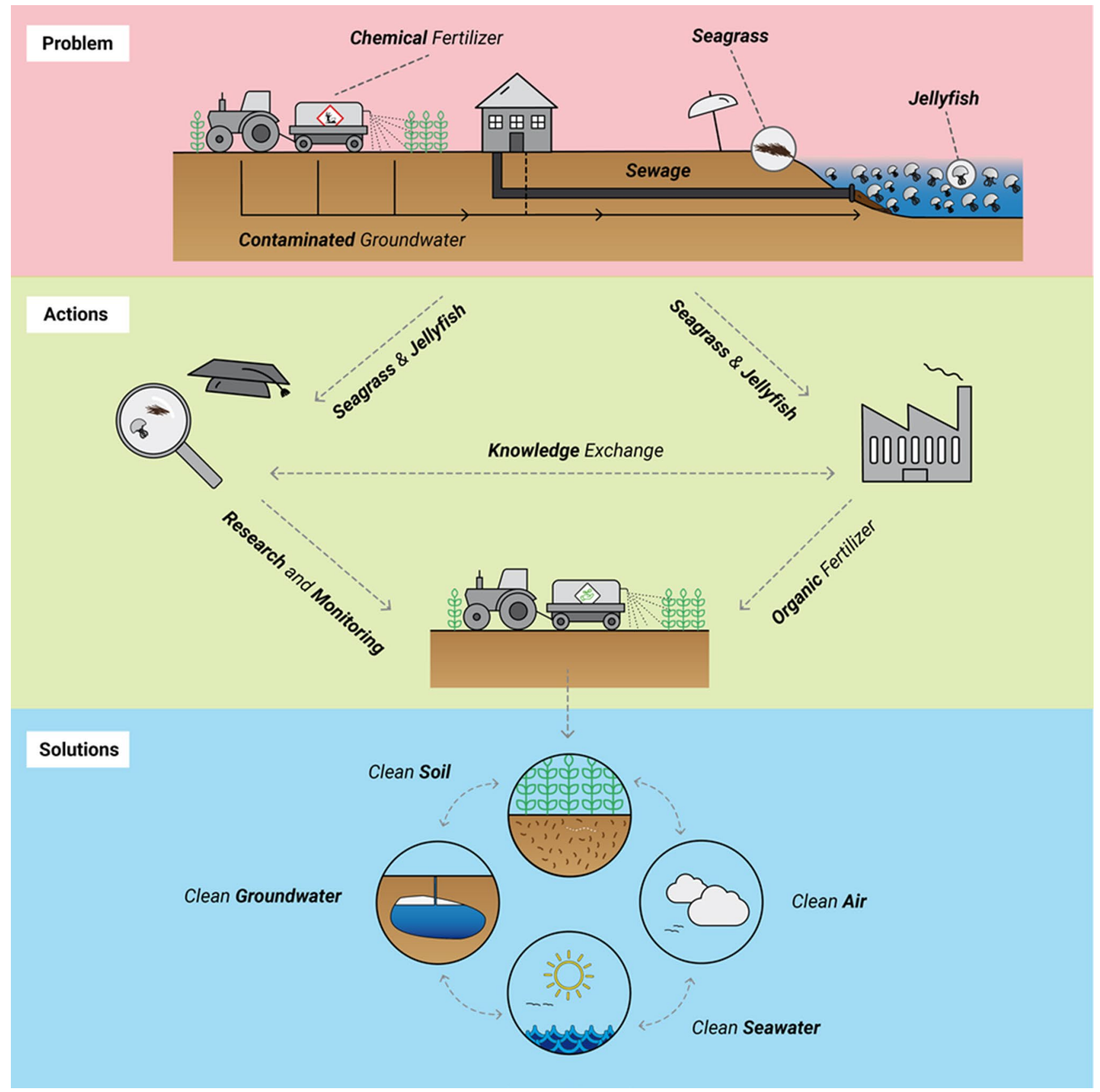

Fig. 2 A schematic representation of the impacts of the use of chemical fertilizers, and of the (positive) consequences of the utilization of seagrass and jellyfish as organic fertilizers on environmental sustainability 
UN General Assembly Resolution A/RES/70/1: "Transforming our world: the 2030 Agenda for Sustainable Development" (UN 2015).

\section{Soil quality improvement}

According to Lal (2015), an important strategy for soil quality restoration is improving the availability of suitable micro- and macro-nutrients. In many of the world's leastdeveloped countries there is still a large yield gap in their agriculture, defined as the ratio between current yield and potential yield. The main problems that need to be addressed to close this gap are the lack of knowledge, technologies and, in many cases, limited access to plant nutrients such as $\mathrm{N}$ and P (Pradhan et al. 2015). Mineral fertilizers are used to a lesser extent than in developed economies because of their price. There is also a global decline in the availability of $\mathrm{P}$ fertilizers and this has led to high prices for phosphate rock, and it is predicted that global reserves may be depleted in 50-100 years (Cordell et al. 2009). Hence, the scarcity of these main nutrients may lead to severe losses in crop yields.

Moreover, large amounts of soil nutrients (both natural origin and those added by chemical fertilizers) are not taken up by the vegetation, and therefore not incorporated into human food or animal feed. The nutrient uptake efficiencies of plants are limited and therefore, some nutrients remain in the soil; accordingly, significant amounts of excess nutrients enter water-courses and eventually the sea, causing water pollution and contamination (Løes 2017). The utilization of marine organic fertilizers would allow the transfer of nutrients from the sea to the soil and could be used in areas that have poor levels of available nutrient resources. Thus, the need for additional mineral fertilizer inputs could be avoided. Therefore, it is assumed that marine organic fertilizers could reduce water pollution by balancing the amount of nutrients between terrestrial and marine ecosystems. Hence, it is presumed that marine organic fertilizers may provide locally valuable resources as an additional and/or alternative organic nutrients for soil restoration by enhancing ecosystem goods and services in coastal areas.

\section{Seagrass and jellyfish as sources of organic fertilizers}

One of the first studies that reviewed the chemical composition of seagrass species was by Duarte (1990) who collected available published data on nutrient contents in the leaves of 27 marine vascular plants from different seagrass communities at 30 locations worldwide. This study indicated that the average concentrations of $\mathrm{C}, \mathrm{N}$ and $\mathrm{P}$ in different angiosperm species (in leaf dry matter, as percent dry weight) were around 33, 1.9 and 0.2, respectively. Milchakova et al. (2014) also reported values for some macro- and microelement compounds in Zostera marina L. from the Black Sea
(Table 1). El Din and El-Sherif (2013) studied the nutritional value of two seagrass species, Cymodocea nodosa (Ucria) Ascherson and P. oceanica (L.) Delile, and their potential for use as fertilizers in the Mediterranean coast of Egypt. In both species the authors found that the concentrations of trace elements were much lower than the EU-permitted limits for composts. However, the concentrations of some major elements in P. oceanica were higher than permitted limits (El Din and El-Sherif 2013), especially sodium levels, which are toxic to root systems at levels higher than $1 \%$ saturation in media (Compost Management Program, 2012). Accordingly, they recommended use of $C$. nodosa only as supplementary powdered organic fertilizer in that area (El Din and El-Sherif 2013).

The application of seagrass-based compost as an organic fertilizer (made from leaves of $P$. oceanica collected in the Adriatic and Ionian Seas) was also investigated in tomato (Lycopersicum esculentum L.) and lettuce (Lactuca sativa L.) Grassi et al. (2015). In the preparation process, the seagrass residues were washed four times with low conductivity water in order to prevent negative effects of sodium chloride; therefore the electrical conductivity (EC) was reduced to $1.20 \mathrm{dS} \mathrm{m}^{-1}$ with low concentrations of $\mathrm{Na}^{+}$and $\mathrm{Cl}^{-}$of around 108 and $163 \mathrm{mg} \mathrm{L}^{-1}$ (Grassi et al. 2015). According to Parente et al. (2013), temporary storage and exposure of the seagrass residues to rain could also be used to reduce the salt content and accelerate the composting process. The

Table 1 Some macro- and microelement compounds of eelgrass (Zostera marina) from the Black Sea (values extracted from Duarte 1990; Milchakova et al. 2014 and Han et al. 2016) and of jellyfish (Aurelia aurita) from the German Baltic coast (according the laboratory analysis by the Institute for Crop Science and Plant Breeding, Kiel, Germany, 2019) as well as values from digestates derived from organic manures $(n=85)$ (adapted from Möller and Schultheiß 2014)

\begin{tabular}{|c|c|c|c|}
\hline \multirow[t]{2}{*}{$\begin{array}{l}\text { Elements in } \\
\text { dry matter }\end{array}$} & Zostera marina & Aurelia aurita ${ }^{\mathrm{a}}$ & $\begin{array}{l}\text { Digestates from } \\
\text { organic manures }\end{array}$ \\
\hline & $\%$ per dry mass & $\%$ per dry mass & $\%$ per dry mass \\
\hline $\mathrm{N}$ & 2.5 & 7.8 & 8.11 \\
\hline $\mathrm{C}$ & 36 & 27.3 & 44.6 \\
\hline $\mathrm{P}$ & 0.17 & 1.0 & 1.45 \\
\hline $\mathrm{Ca}$ & 2.48 & 0.75 & - \\
\hline $\mathrm{Mg}$ & 1.15 & 1.0 & 0.73 \\
\hline $\mathrm{Na}$ & 1.0 & 9.2 & 0.21 \\
\hline K & 0.7 & 0.44 & 6.45 \\
\hline S & 0.6 & - & 0.55 \\
\hline $\mathrm{Fe}$ & 0.45 & 0.04 & 0.53 \\
\hline $\mathrm{Mn}$ & 0.08 & $<0.01$ & 0.06 \\
\hline $\mathrm{Cu}$ & 0.003 & $<0.01$ & 0.01 \\
\hline $\mathrm{Zn}$ & 0.01 & 0.04 & 0.03 \\
\hline C:N-ratio & 14.4 & 3.5 & 5.5 \\
\hline
\end{tabular}

\footnotetext{
${ }^{a}$ Alcohol dried
} 
results of Grassi et al. (2015) indicated that such organic compost had positive effects on soil chemical properties, with increasing $\mathrm{K}$ and $\mathrm{P}$ contents in soil. Moreover, they found a positive effect of seagrass residues on tomato production, probably due to enhancing the soil water holding capacity. They also recorded increased concentrations of $\alpha$-tocopherol in tomato fruits, thereby improving the nutritional value of the fruit. Grassi et al. (2015) also concluded that the use of $P$. oceanica residues confers several advantages including release of nutrients to the soil, reduced use of commercial herbicides and opportunities to dispense with polyethylene plastic mulches.

The use of residues of $P$. oceanica on the soil provides a barrier against water losses, as it acts to shade the soil surface and thereby reduce evapotranspiration (Grassi et al. 2015). These authors also found that in deep soil layers (where most of the root systems occur) the soil water content was higher on treatments with $P$. oceanica mulching than without seagrass mulching (Grassi et al. 2015). Positive effects of Syringodium isoetifolium on the growth and production of crops such as tomato and water-melon have also been reported (N'Yeurt and Iese 2014) from Beqa Island, Fiji. The value of seagrasses for agricultural purposes has been stressed further on the basis of evidence describing their elemental composition (Milchakova et al. 2014).

Results from several studies have reported that dried jellyfish used as a fertilizer improves the physical structure and bacterial communities of the soil, the likely mechanism being by enhancing soil moisture and supplying nutrients, which could promote survival and growth of plant seedlings (Tinta et al. 2010, 2012, 2016; Blanchet et al. 2014; Seo et al. 2014). Hussein et al. (2015) examined the application of liquefied jellyfish on seedling growth and as an organic insecticide for pest control. However, despite the successful effects reported in the literature, further large-scale investigations are required before utilizable fertilizer can be produced from jellyfish. According to Ezaki et al. (2008, 2011) jellyfish fertilizer can absorb approximately eight times its own weight in water. This property makes jellyfish fertilizer of potential value for restoration of dryland areas by enhancing water use efficiency, though this still has not been investigated in detail. Seo et al. (2014) studied the application of jellyfish (Nemopilema nomurai Kishinouye) as a fertilizer to enhance the growth of plants in degraded soil and for early restoration in burned forest areas. The study was conducted in a temperate climate area, with mean annual precipitation ranging from around $1100 \mathrm{~mm}$ to about $2000 \mathrm{~mm}$, where water erosion control was the main purpose, and the spatial, temporal and economic restrictions were not considered. The authors also indicated that the application of jellyfish fertilizer increased soil contents of organic matter, N, P and $\mathrm{K}$, and enhanced growth and survival of Pinus thunbergii and Quercus palustris seedlings (Seo et al. 2014). Hossain et al. (2013) found that the total dry weight of rice plants was much higher in plots that received desalinated dried jellyfish compared with rice bran-treated plots, possibly because of higher $\mathrm{N}$ concentration of the jellyfish. They also emphasized that rice bran and desalinated dried jellyfish controlled weeds better when mixed with soil before planting. Jellyfish also contain considerable amounts of the principle plant nutrients (N, P, K, magnesium and calcium) and trace elements (Table 1) which enhance the growth rates of plants, and also contain very low levels of harmful elements, including lead $(\mathrm{Pb})$, mercury $(\mathrm{Hg})$, arsenic (As) and cadmium (Cd) (Fukushi et al. 2003). Moreover, compared with other organic manures or seagrass, it has a narrow C:N-ratio, indicating a fast plant availability of nutrients. However, salt contents can be critical, particularly when no washing or no dilution of salt was performed in the pre-treatment. In agriculture, jellyfish has been tested successfully for rice growth and as a method of weed control; a significant increase of yield (up to five times, compared to yield from non-fertilized soil) and decrease in weed numbers of up to 30 times was reported by Hossain et al. (2013). Jellyfish was also applied as a fertilizer on different trees-Japanese red pine (Pinus densiflora) and oak (Quercus acutissima) - where it was shown that a low amount of jellyfish fertilizer in the soil $\left(1.6 \mathrm{~g} \mathrm{~kg}^{-1}\right)$ could increase the soil moisture and nutrient contents, consequently enhancing the seedling growth (Woo Chun et al. 2011).

\section{Future perspectives on using marine organic fertilizers}

Higher demands from an increasing human population are contributing to serious environmental problems, in different forms, in almost all areas of the world. Therefore, sustainable consumption patterns that meet human needs, improve the quality of lives, and reduce pollutants in the product life cycle are urgently needed (Wang et al. 2019). According to Moldan et al. (2012) sustainable development processes should firstly focus on human wellbeing and demand. Secondly, human life should be healthy, productive and in harmony with the natural environment. Thirdly, an important dimension of sustainability is the dynamic and long-term nature which needs to consider present and future generations. Marine organic fertilizers could be considered as 'environment-friendly', since their production and utilization follow the targets of integrative management of coastal areas, currently considered as 'blue growth' in context of strategy for supporting sustainable management in marine sectors (Lillebø et al. 2017). This could also contribute to achieving some of the goals of sustainable development in the near future. It should be emphasized that many coastal areas of the world 
are suffering damage from industrialization, agricultural operations and urbanization (Islam and Tanaka 2004). Chemical fertilizers and pesticides are a source of contaminants that are damaging marine ecosystems (Doney et al. 2012). Application of chemical fertilizers may also increase heavy metal contamination in the soil, in particularly with $\mathrm{Cd}, \mathrm{Pb}$, and As (Atafar et al. 2010). Therefore, it is assumed that the sustainable utilization of marine resources as organic fertilizers would provide essential elements for soil, and therefore, their use as an alternative to chemical fertilizers could help mitigate the impacts that are responsible for soil and marine contamination. It should also be pointed that a wide range of aquatic organisms could be potential source of contamination e.g. by accumulating microplastics (Sun et al. 2017; Sharma and Chatterjee 2017), therefore, further work is needed to stablish the viability of utilization of seagrass and jellyfish as new resources to be used for any large-scale applications.

\section{Conclusions}

The objective of this review paper was to consider marine organic fertilizers as an alternative source for integrated land management, especially in coastal areas that are facing problems with jellyfish bloom and the effects of seagrass waste, as well as soil degradation and marine contamination. For this purpose, an assumption that marine organic fertilizers produced from seagrass and jellyfish could help integrated land management and can be an important and sustainable alternative. Only a few research studies have been conducted to test the use of seagrass and jellyfish as fertilizers. The available results indicate that seagrass and jellyfish have great potential for use as alternative fertilizers because of their content of essential macro- and microelements that are important for soil and plants. The use of such fertilizers has been shown to enhance the soil water holding capacity, as well as promoting seed germination and seedling establishment. We hope the findings of this review will help increase scientific interest in this research topic and its application, and help identify further important opportunities for investigation.

Acknowledgements Open Access funding provided by Projekt DEAL. The authors would like to thank anonymous reviewers for their constructive comments and suggestions, and also acknowledge the European Union's Horizon 2020 research and innovation programme (Grant agreement no. 774499) for funding the GoJelly project.

Open Access This article is licensed under a Creative Commons Attribution 4.0 International License, which permits use, sharing, adaptation, distribution and reproduction in any medium or format, as long as you give appropriate credit to the original author(s) and the source, provide a link to the Creative Commons licence, and indicate if changes were made. The images or other third party material in this article are included in the article's Creative Commons licence, unless indicated otherwise in a credit line to the material. If material is not included in the article's Creative Commons licence and your intended use is not permitted by statutory regulation or exceeds the permitted use, you will need to obtain permission directly from the copyright holder. To view a copy of this licence, visit http://creativecommons.org/licenses/by/4.0/.

\section{References}

Adolwa IS, Schwarze S, Waswa B, Buerkert A (2017) Understanding system innovation adoption: a comparative analysis of integrated soil fertility management uptake in Tamale (Ghana) and Kakamega (Kenya). Renew Agric Food Syst 34:313-325

Arora NK, Fatima T, Mishra I, Verma M, Mishra J, Mishra V (2018) Environmental sustainability: challenges and viable solutions. Environ Sustain 1(4):309-350

Atafar Z, Mesdaghinia A, Nouri J, Homaee M, Yunesian M, Ahmadimoghaddam $M$ et al (2010) Effect of fertilizer application on soil heavy metal concentration. Environ Monit Assess 160:83-89

Badgley C, Moghtader J, Quintero E, Zakem E, Chappell MJ, AvilesVazquez K, Samulon A, Perfecto I (2007) Organic agriculture and the global food supply. Renew Agric Food Syst 22:86-108

Bedunah DJ, Angerer JP (2012) Rangeland degradation, poverty, and conflict: how can rangeland scientists contribute to effective responses and solutions? Rangel Ecol Manag 65:606-612

Blanchet M, Pringault O, Bouvy M, Catala P, Oriol L, Caparros J, Ortega-Retuerta E, Intertaglia L, West N, Agis M, Got P, Joux $F$ (2014) Changes in bacterial community metabolism and composition during the degradation of dissolved organic matter from the jellyfish Aurelia aurita in a Mediterranean coastal lagoon. Environ Sci Pollut Res 22:13638-13653

Boero F (2013) Review of jellyfish blooms in the Mediterranean and Black Sea. GFCM Studies and Reviews, vol 92

Bonanno G, Orlando-Bonaca M (2017) Trace elements in Mediterranean seagrasses: accumulation, tolerance and biomonitoring. A review. Mar Pollut Bull 125:8-18

Borum J, Greve TM (2004) The four European seagrass species. In: Borum J, Duarte CM, Krause-Jensen D, Greve TM (eds) European seagrasses: an introduction to monitoring and management. The M\&MS project, ISBN: 87-89143-21-3. pp 1-8

Boström C, Roos C, Ronnberg O (2004) Shoot morphometry and production dynamics of eelgrass in the northern Baltic Sea. Aquat Bot 79:145-161

Boström C, Baden S, Bockelmann A, Dromph K, Fredriksen S, Gustafsson C et al (2014) Distribution, structure and function of Nordic eelgrass (Zostera marina) ecosystems: implications for coastal management and conservation. Aquat Conserv Mar Freshw Ecosyst 24:410-434

Brankatschk G, Finkbeiner M (2017) Crop rotations and crop residues are relevant parameters for agricultural carbon footprints. Agron Sustain Dev 37:58

Christiansen JR, Vesterdal L, Gundersen P (2012) Nitrous oxide and methane exchange in two small temperate forest catchmentseffects of hydrological gradients and implications for global warming potentials of forest soils. Biogeochemistry 107:437-454

Compost Management Program (2012) Compost analysis for available nutrients and soil suitability criteria and evaluation. A\&L Canada Laboratories. https://alcanada.com/pdf/Compo st_Handbook.pdf

Condon RH, Steinberg DK, del Giorgio PA, Bouvier TC, Bronk DA, Graham WM, Ducklow HW (2011) Jellyfish blooms result in a 
major microbial respiratory sink of carbon in marine systems. Proc Natl Acad Sci 108:10225-10230

Cordell D, Drangert JO, White S (2009) The story of phosphorus: global food security and food for thought. Glob Environ Change. 19:292-305

Costanza R, d'Argue R, de Groot R, Farber S, Grasso M, Hannon B, Limburg K, Naeem S, O’Neill RV, Paruelo J, Raskin RG, Sutton P, van den Belt M (1997) The value of the world's ecosystem services and natural capital. Nature 387:253-260

Davenport J, Davenport JL (2006) The impact of tourism and personal leisure transport on coastal environments: a review. Estuar Coast Shelf Sci 1:280-292

De Donno A, Idolo A, Bagordo F, Grassi T, Leomanni A, Serio F, Guido M, Canitano M, Zampardi S, Boero F, Piraino S (2014) Impact of stinging jellyfish proliferations along South Italian coasts: human health hazards, treatment and social costs. Int J Environ Res Public Health 11:2488-2503

De la Torre-Castro M, Rönnbäck P (2004) Links between humans and seagrasses: an example of tropical East Africa. Ocean Coast Manag 47:361-387

Den Hartog C (1970) The Sea-grasses of the World. North Holland Publ. Co., Amsterdam, p 274

Dobbie KE, McTaggart IP, Smith KA (1999) Nitrousoxide emissions from intensive agricultural systems: variations between crops and seasons, keydriving variables, and mean emission factors. J Geophys Res 26:891-899

Doney SC, Ruckelshaus M, Duffy JE, Barry JP, Chan F, English CA, Galindo HM, Grebmeier JM, Hollowed AB, Knowlton N, Polovina J, Rabalais NN, Sydeman WJ, Talley LD (2012) Climate change impacts on marine ecosystems. Ann Rev Mar Sci 4:11-37

Duarte KM (1990) Seagrass nutrient content. Mar Ecol Prog Ser 67:201-207

El Din NGS, El-Sherif ZM (2013) Nutritional value of Cymodocea nodosa and Posidonia oceanica along the western Egyptian Mediterranean coast. Egypt J Aquat Res 30:153-165

Emadodin I, Bork HR (2012) Degradation of soils as a result of longterm human-induced transformation of the environment in Iran: an overview. J Land Use Sci 7:203-219

Emadodin I, Reiss S, Bork HR (2009) A study of the relationship between land management and soil aggregate stability (case study near Albersdorf, Northern-Germany). ARPN J Agric Biol Sci 4:48-53

Emadodin I, Reinsch T, Taube F (2019) Drought and desertification in Iran. Hydrology 6:66

Eriksen E, Prozorkevich D, Trofimov A, Howell D (2012) Biomass of scyphozoan jellyfish, and its spatial association with 0-group fish in the Barents Sea. PLoS One 7(3):e33050

European Commission (2012) Blue growth opportunities for marine and maritime sustainable growth. Publications Office of the European Union, Luxembourg. https://ec.europa.eu/maritimeaffairs/sites/maritimeaffairs/files/docs/publications/blue-growth en.pdf (ISBN 978-92-79-25529-8)

Ezaki T, Kohno S, Edashige T, Cha DS, Chun KW (2008) Development of the revegetation material which using dried jellyfish (Nemopilema nomurai) powder. J Jpn Soc Reveg Technol 34:195-198

Ezaki T, Kohno S, Tetsuro K, Chun KW, Damdinsuren E (2011) The effect of jellyfish fertilizer on tree growth in hillside erosion control works. J Jpn Soc Reveg Technol 37:151-154

FAO (2009) How to Feed the World in 2050? Food and Agriculture Organization, Rome. http://www.fao.org/fileadmin/templates/ wsfs/docs/expert_paper/How_to_Feed_the_World_in_2050.pdf

FAO (2017) World fertilizer trends and outlook to 2020, summary report. Food and Agriculture Organization of the United Nation, Rome
FAO (2019) Fertilizers by Product. http://www.fao.org/faostat/ en/\#data/RFB

Filipkowska A, Lubecki L, Szymczak-Zyla M, Kowalewska G (2009) Factors affecting the occurrence of algae on the Sopot beach (Baltic Sea). Oceanologia 51:233-262

Fukushi K, Ishio N, Tsujimoto J, Yokota K, Hamatake T, Sogabe H, Toriya K, Nimomiya T (2003) Preliminary study on the potential usefulness of jellyfish fertilizer. J Bull Soc Sea Water Sci 2:209-217

Gibbons MJ, Richardson AJ (2013) Beyond the jellyfish joyride and global oscillations: advancing jellyfish research. J Plankton Res 35:929-938

Graham WM, Gelcich S, Robinson KL, Duarte CM, Brotz L, Purcell JE, Madin LP, Mianzan H, Sutherland KR, Uye SI, Pitt KA, Lucas CH, Bøgeberg M, Brodeur RD, Condon RHA (2014) Linking human well-being and jellyfish: ecosystem services, impacts, and societal responses. Front Ecol Environ $12: 515-523$

Grassi F, Mastrorilli M, Mininni C, Parente A, Santino A, Scarcella M, Santamaria P (2015) Posidonia residues can be used as organic mulch and soil amendment for lettuce and tomato production. Agron Sustain Dev 35:679-689

Guo J, Liu X, Zhang Y, Shen J, Han W, Zhang W, Christie P, Goulding KWT, Vitousek PM, Zhang F (2010) Significant acidification in major Chinese croplands. Science 327:1008-1010

Hämmerli A (2002). Evolutionary genetics of eelgrass clones in the Baltic Sea. Ph.D. Thesis, Christian-Albrechts-Universität, Kiel

Han Q, Soissons LM, Bouma TJ, van Katwijk MM, Liu D (2016) Combined nutrient and macroalgae loads lead to response in seagrass indicator properties. Mar Pollut Bull 106:174-182

Harrison PG (1989) Detrital processing in seagrass systems: a review of factors affecting decay rates, remineralization and detritivory. Aquat Bot 35:263-288

Hatfield J (2012) Agriculture in the Midwest. In: Winkler J, Andresen J, Hatfield J, Bidwell D, Brown D (eds) coordinators. U.S. National Climate Assessment Midwest Technical Input Report. Available from the Great Lakes Integrated Sciences and Assessments (GLISA) Center. http://glisa.msu.edu/docs/NCA/MTIT_ Agriculture.pdf

He W, Jiang R, He P, Yang J, Zhou W, Ma J, Liu Y (2018) Estimating soil nitrogen balance at regional scale in China's croplands from 1984 to 2014. Agric Syst 167:125-135

Hemminga MA, Duarte CM (2000) Seagrass ecology. Cambridge University Press, Cambridge

Heywood VH (1996) Flowering plants of the world. B T Batsford Ltd, London

Hossain ST, Sugimoto H, Asagi N, Araki T, Ueno H, Morokuma M, Kato H (2013) The use of desalinated-dried jellyfish and rice bran for controlling weeds and rice yield. J Org Syst 8:28-37

Hubbard DM, Dugan JE (2003) Shorebird use of an exposed sandy beach in southern California beaches-what future? Estuar Coast Shelf Sci 1:41-54

Hussein OS, Sayed RM, Saleh OI (2015) Uses of jellyfish in pre sowing seeds treatment and pest control. Am J Exp Agric 5:60-69

Islam MS, Tanaka M (2004) Impacts of pollution on coastal and marine ecosystems including coastal and marine fisheries and approach for management: a review and synthesis. Mar Pollut Bull 48:624-649

Kenworthy WJ, Fonseca MS (1992) The use of fertilizer to enhance growth of transplanted seagrasses Zostera marina L. and Halodule wrightii Aschers. J Exp Mar Biol Ecol 163:141-161

Lal R (2006) Enhancing crop yields in the developing countries through restoration of the soil organic carbon pool in agricultural lands. Land Degrad Dev 17:197-209

Lal R (2015) Restoring soil quality to mitigate soil degradation. Sustainability 7:5875-5895 
Lillebø AI, Pita C, Rodrigues JG, Ramos S, Villasante S (2017) How can marine ecosystem services support the blue growth agenda? Mar Policy 81:132-142

Lipkin Y, Beer S, Zakai D (2003) The seagrasses of the eastern Mediterranean and the Red Sea. In: Green EP, Short FT (eds) World atlas of seagrasses. University of California Press, Berkeley

Lobell DB, Schlenker W, Costa-roberts J (2011) Climate trends and global crop production since 1980. Science 333:616-620

Løes AK (2017) Marine rest raw materials for fertilizers to organic agriculture (RESTOR). https://www.norsok.no/en/projects/2017/ marine-rest-raw-materials-for-fertilizers-to-organic-agricultur e-restor

Loges R, Bunne I, Reinsch T, Malisch C, Kluß C, Herrmann A, Taube $\mathrm{F}$ (2018) Forage production in rotational systems generates similar yields compared to maize monocultures but improves soil carbon stocks. Eur J Agron 97:11-19

Lucas CH, Gelcich S, Uye SI (2014) Living with jellyfish: management and adaptation strategies. In: Pitt KA, Lucas CH (eds) Jellyfish blooms. Springer, Dordrecht, pp 129-150

Miao YX, Stewart BA, Zhang FS (2011) Long-term experiments for sustainable nutrient management in China. A review. Agron Sustain Dev 31:397-414

Mikkelsen RL, Bruulsema TW (2005) Fertilizer use for horticultural crops in the US during the 20th century. HortTechnology 15:24-30

Milchakova NA (2008) Role of marine protected areas in the conservation of the Azov-and-Black Sea region biodiversity. In: Proceedings of the IV international conference present aspects of the ecology of the Azov-and-Black Sea Region, Kerch, 10 Oct 2008, Kerch, pp 162-168

Milchakova NA, Böer B, Boyko LI, Mikulich DV (2014) The chemical composition and technological properties of sea grasses a basis for their use (a review). In: Khan MA et al (eds) Sabkha ecosystems: volume IV: cash crop halophyte and biodiversity 313 conservation, tasks for vegetation science 47 . Springer, Dordrecht

Millennium Ecosystem Assessment (2005) Ecosystems and human well-being: current state and trends findings of condition and trends working group. Island Press, Washington, DC, p 948

Mishra DJ, Singh R, Mishra UK, Kumar SS (2013) Role of bio-fertilizer in organic agriculture: a review. Res J Recent Sci 2:239-241

Moldan B, Janouskova S, Hak T (2012) How to understand and measure environmental sustainability: indicators and targets. Ecol Indic 17:4-13

Möller K, Schultheiß U (2014) Organische Handelsdüngemittel im ökologischen Landbau. Publisher Kuratorium für Technik und Bauwesen in der Landwirtschaft e.V. (KTBL). ISBN 978-3-941583-89-4

Mossbauer M, Haller I, Dahlke S, Schernewski G (2012) Management of stranded eelgrass and macroalgae along the German Baltic coastline. Ocean Coast Manag 57:1-9

Murugan R, Loges R, Taube F, Joergensen RG (2013) Specific response of fungal and bacterial residues to one-season tillage and repeated slurry application in a permanent grassland soil. Appl Soil Ecol 72:31-40

N'Yeurt AR, Iese V (2014) Sustainable agro-fertilizers from marine plants in Pacific Small Island Developing States (SIDS). In: Ganpat Wayne $\mathrm{G}$ (ed) Impacts of climate change on food security in small island developing states. The University of the West Indies/ IGI Global, St Augustine

Omori M, Nakano E (2001) Jellyfish fisheries in southeast Asia. Hydrobiologia 451:19-26

Orlando-Bonaca MJ, Francé B, Mavrič M, Grego L, Lipej V, FlanderPutrle Šiško M, Falac A (2015) A new index (MediSkew) for the assessment of the Cymodocea nodosa (Ucria) Ascherson meadow's status. Mar Environ Res 110:132-141
Parente A, Montesano F, Lomoro A, Guido M (2013) Improvement of beached Posidonia residues performance to composting. Environ Eng Manag J 12:81-84

Pauly D, Graham W, Libralato S, Morissette L, Palomareset MLD (2009) Jellyfish in ecosystems, online databases, and ecosystem models. Hydrobiologia 616:67-85

Phelan P, Moloney AP, McGeough EJ, Humphreys J, Bertilsson J, O'Riordan EG, O'Kiely P (2015) Forage legumes for grazing and conserving in ruminant production systems. Crit Rev Plant Sci 34:281-326

Pradhan P, Fischer G, van Velthuizen H, Reusser DE, Kropp JP (2015) Closing yield gaps: how sustainable can we be? PLoS ONE 10(6):e0129487. https://doi.org/10.1371/journal.pone.0129487

P.R.I.M.E (LIFE + PROJECT: Posidonia residues integrated management for eco-sustainability) (2014) Final Report (extract) covering the project activities from 01/09/2010 to 30/12/2013. http:// www.eco-logicasrl.it/lifeprime/wp-content/uploads/2012/04/ final_report_PRIME_giugno14-SINTESI_Rev0.pdf. Accessed 15 May 2014

Prosekov AY, Ivanova SA (2018) Food security: the challenge of the present. Geoforum 91:73-77

Purcell J (2005) Climate effects on formation of jellyfish and ctenophore blooms: a review. J Mar Biol Assoc UK 85:461-476. https://doi.org/10.1017/S0025315405011409

Purcell J, Uye S, Lo W (2007) Anthropogenic causes of jellyfish blooms and their direct consequences for humans: a review. Mar Ecol Prog Ser 350:153-174

Rahmati O, Nazari Samani A, Mahmoodi N, Mahdavi M (2015) Assessment of the contribution of $\mathrm{N}$-fertilizers to nitrate pollution of groundwater in western Iran (case study: GhorvehDehgelan Arquifer). Water Qual Expo Health 7:143-151

Rashid MA, Mujawar LH, Shahzad T, Almeelbi T, Ismail IMI, Oves M (2016) Bacteria and fungi can contribute to nutrients bioavailability and aggregate formation in degraded soils. Microbiol Res 183:26-41

Reinsch T, Loges R, Kluß C, Taube F (2018) Renovation and conversion of permanent grass-clover swards to pasture or crops: effects on annual $\mathrm{N}_{2} \mathrm{O}$ emissions in the year after ploughing. Soil Tillage Res 175:119-129

Sathya B, Indu H, Seenivasan R, Geetha S (2010) Influence of seaweed liquid fertilizer on the growth and biochemical composition of legume crop, Cajanus cajan (L.) Mill sp. J Phytol 2:50-63

Schmeer M, Loges R, Dittert K, Senbayram M, Horn R, Taube F (2014) Legume-based forage production systems reduce nitrous oxide emissions. Soil Tillage Res 143:17-25

Seo J, Kim YR, Otsuki K, Kim SW, Yeom KJ, Jae-Seon Yi JS, Ahn YS, Ezaki T, Chun KW (2014) Contributions of jellyfish fertilizer to survival and growth of seedlings planted in a recently burned forest, Republic of Korea. J Fac Agric Kyushu Univ 59:181-189

Sharma S, Chatterjee S (2017) Microplastic pollution, a threat to marine ecosystem and human health: a short review. Environ Sci Pollut Res 24:21530-21547

Short FT (1987) Effects of sediment nutrients on seagrasses, literature review and mesocosm experiment. Aquat Bot 27:41-57

Short FT, Carruthers TJB, Dennison WC, Waycott M (2007) Global seagrass distribution and diversity: a bioregional model. J Exp Mar Biol Ecol 350:3-20

Spalding MD, Taylor M, Ravilious C, Short FT, Green EP (2003) The distribution and status of seagrass. In: Green EP, Short FT (eds) World atlas of seagrasses. UNEP-WCMC, Collection biodiversity, Cambridge, p 336

Steinfeld HP, Gerber P, Wassenaar T, Castel V, Rosales M, de Haan C (2006) Livestock's long shadow: environmental issues and options. FAO, Rome 
Sun X, Li Q, Zhu M, Liang J, Zheng S, Zhao Y (2017) Ingestion of microplastics bynatural zooplankton groups in the northern South China Sea. Mar Pollut Bull 115:217-224

Taube F, Gierus M, Hermann A, Loges R, Schönbach P (2014) Grassland and globalization-challenges for north-west European grass and forage research. Grass Forage Sci 69:2-16

Terrados J, Borum J (2004) Why are seagrasses important? Goods and services provided by seagrass meadows. In: Borum J, Duarte CM, Krause-Jensen D, Greve TM (eds) European seagrasses: an introduction to monitoring and management. The M\&MS project, Amsterdam, pp 8-10

Thierfelder C, Rusinamhodzi L, Ngwira AR, Mupangwa W, Nyagumbo I, Kassie GT, Cairns JE (2015) Conservation agriculture in southern Africa: advances in knowledge. Renew Agric Food Syst 30:328-348

Tinta T, Malej A, Kos M, Turk V (2010) Degradation of the Adriatic medusa Aurelia sp. by ambient bacteria. Hydrobiologia 645:179-191

Tinta T, Kogovšek T, Malej A, Turk V (2012) Jellyfish modulate bacterial dynamic and community structure. PLoS One 7:e39274

Tinta T, Kogovšek T, Turk V, Shiganova TA, Mikaelyan AS, Malej A (2016) Microbial transformation of jellyfish organic matter affects the nitrogen cycle in the marine water column-a Black Sea case study. J Exp Mar Biol Ecol 473:19-30

UN (2015) United Nations Official Document. https://www.un.org/ga/ search/view_doc.asp?symbol=A/RES/70/1\&Lang $=\mathrm{E}$

Verlaque M, Ruitton S, Mineur F, Boudouresque CF (2015) CIESM Atlas of exotic species of the Mediterranean. Macrophytes. CIESM, Monte Carlo, pp 1-36

Vimal SR, Singh JS, Arora NK, Singh S (2017) Soil-plant-microbe interactions in stressed agriculture management: a review. Pedosphere 27:177-192

Wahab I, Madduppa H, Kawaro M (2017) Seagrass species distribution, density and coverage. IOP Conf Ser: Earth Environ Sci 54:012084

Wang Z, Xue M, WangY Song M, Li S, Daziano RA, Wang B, Ma G, Chen K, Li X, Zhang B (2019) Big data: new tend to sustainable consumption research. J Clean Prod. https://doi.org/10.1016/j. jclepro.2019.06.330

Woo Chun K, Enkhjargal D, Yeom K, Ezaki T (2011) Effect of jellyfish fertilizer application on seedling growth. J Jpn Soc Reveg Technol 37:155-158

Worm B, Reusch T (2000) Do nutrient availability and plant density limit seagrass colonization in the Baltic Sea? Mar Ecol Prog Ser 200:159-166

Wyllie-Echeverria S, Cox PA (1999) The seagrass Zostera marina [Zosteraceae] industry of Nova Scotia (1907-1960). Econ Bot 53:419-426

You K, Ma C, Gao H, Li F, Zhang M, Qiu YY, Wang B (2007) Research on the jellyfish (Rhopilema esculentum Kishinouye) and associated aquaculture techniques in China: current status. Aquacult Int 15:479-488

Yu H, Liu X, Dong X, Li C, Xing R, Liua S, Lia P (2005) Insecticidal activity of proteinous venom from tentacle of jellyfish Rhopilema esculentum Kishinouye. Bioorg Med Chem Lett 15:4949-4952

Yu H, Li R, Dong X, Xing R, Liu S, Li P (2014) Efficacy of venom from tentacle of jellyfish Stomolophus meleagris (Nemopilema nomurai) against the Cotton Bollworm Helicoverpa armigera. Biomed Res Int. https://doi.org/10.1155/2014/31585

Zhang K, Yu Z, Li X, Zhou W, Zhang D (2007) Land use change and land degradation in China from 1991 to 2001. Land Degrad Dev 18:209-219

Zhuang Y, Hou H, Zhao X, Zhang Z (2009) Effects of collagen and collagen hydrolysate from jellyfish (Rhopilema esculentum) on mice skin photoaging induced by UV irradiation. J Food Sci 74:1883-1888

Publisher's Note Springer Nature remains neutral with regard to jurisdictional claims in published maps and institutional affiliations. 